\title{
Laser Beam Welding of a Low Density Refractory High Entropy Alloy
}

\author{
Evgeniya Panina ${ }^{1,2, *}$, Nikita Yurchenko ${ }^{1}$, Sergey Zherebtsov ${ }^{1}(0)$, Nikita Stepanov ${ }^{1}(\mathbb{D}$, \\ Gennady Salishchev ${ }^{1}{ }^{\oplus}$, Volker Ventzke ${ }^{2}$, René Dinse ${ }^{2}$ and Nikolai Kashaev ${ }^{2}$ \\ 1 Laboratory of Bulk Nanostructured Materials, Belgorod National Research University, Pobeda 85, \\ Belgorod 308015, Russia; yurchenko_nikita@bsu.edu.ru (N.Y.); zherebtsov@bsu.edu.ru (S.Z.); \\ stepanov@bsu.edu.ru (N.S.); salishchev@bsu.edu.ru (G.S.) \\ 2 Department of Laser Processing and Structural Assessment, Institute of Materials Research, \\ Materials Mechanics, Helmholtz-Zentrum Geesthacht, Max-Planck-Str. 1, 21502 Geesthacht, Germany; \\ volker.ventzke@hzg.de (V.V.); rene.dinse@hzg.de (R.D.); nikolai.kashaev@hzg.de (N.K.) \\ * Correspondence: panina_e@bsu.edu.ru; Tel.: +7-472-258-5416
}

Received: 12 November 2019; Accepted: 11 December 2019; Published: 16 December 2019

check for updates

\begin{abstract}
The effect of laser beam welding on the structure and properties of a $\mathrm{Ti}_{1.89} \mathrm{NbCrV}_{0.56}$ refractory high entropy alloy was studied. In particular, the effect of different pre-heating temperatures was examined. Due to the low ductility of the material, laser beam welding at room temperature resulted in the formations of hot cracks. Sound butt joints without cracks were produced using pre-heating to $\mathrm{T} \geq 600^{\circ} \mathrm{C}$. In the initial as-cast condition, the alloy consisted of coarse bcc grains with a small amount of lens-shaped C15 Laves phase particles. A columnar microstructure was formed in the welds; the thickness of the grains increased with the temperature of pre-heating before welding. The Laves phase particles were formed in the seams after welding at $600{ }^{\circ} \mathrm{C}$ or $800{ }^{\circ} \mathrm{C}$, however, these particles were not observed after welding at room temperature or at $400^{\circ} \mathrm{C}$. Soaking at elevated temperatures did not change the microstructure of the base material considerably, however, "additional" small Laves particles formed at $600{ }^{\circ} \mathrm{C}$ or $800{ }^{\circ} \mathrm{C}$. Tensile test of welded specimens performed at $750{ }^{\circ} \mathrm{C}$ resulted in the fracture of the base material because of the higher hardness of the welds. The latter can be associated with the bcc grains refinement in the seams.
\end{abstract}

Keywords: high entropy alloys; laser beam welding; microstructure; mechanical properties

\section{Introduction}

There is a strong need for the development of novel metallic materials, which would be able to withstand high temperatures for use in critical industries, including aerospace or energy [1]. Meanwhile, suitable commercial alloys (like Ni-based superalloys) do not provide many opportunities for further improvements. Therefore, new alloying concepts must be explored. One of the concepts is associated with so-called high entropy alloys (HEAs)-alloys, composed of several principal components taken in close to equiatomic proportions [2,3]. These alloys were found to possess some unusual properties outperforming conventional materials, which makes HEAs attractive for a variety of applications [3-6].

For example, HEAs, that are composed of refractory elements (refractory high entropy alloys (RHEAs) [7]), were introduced by Senkov and co-workers almost a decade ago [8]. Due to the striking ability to maintain high strengths at extraordinary high temperatures of $\sim 1600{ }^{\circ} \mathrm{C}$ [9], RHEAs have instantly attracted considerable attention from the scientific community. First, RHEAs composed of $\mathrm{Nb}$, Mo, Ta, $\mathrm{V}$, and $\mathrm{W}$ were too heavy: $\sim 12.0-14.0 \mathrm{~g} / \mathrm{cm}^{3}[8,9]$. Such a high density made their potential usage in the aerospace industry quite questionable, despite the impressive high-temperature strength. Therefore, significant efforts were undertaken to produce alloys with lower density, but superior 
high-temperature strength, by using refractory elements with lower specific gravity like Ti and $\mathrm{Cr}[10,11]$ and/or by adding light elements like Al [12,13]. Many new alloys with densities in the range $\sim 5.5-8.0 \mathrm{~g} / \mathrm{cm}^{3}$ (i.e., lighter than the Ni-based superalloys) were introduced; some of them demonstrated highly attractive specific strength at temperatures up to $1200^{\circ} \mathrm{C}[7,14-21]$.

High (specific) strength itself does not guarantee the applicability of structural materials, since many other properties are critically important as well [22]. For example, technological properties of RHEAs, which are essential for different products fabrication, remain mostly unexplored. Some alloys have demonstrated reasonable workability at room temperature allowing cold rolling to a high thickness reduction. However, the number of cold-workable RHEAs is quite limited [23-26] so far. Most RHEAs have quite low ductility at room temperature even in compression and thus can be processed at high temperatures only [7].

Weldability is another crucial technological property of the structural materials, since welding is one of the most reliable and efficient ways of joining different parts together. A few studies on welding of HEAs were reported recently [27-32]. The efficiency of using arc welding [28], laser beam welding (LBW) [31], electron beam welding [27,28], and friction stir welding [29,30,32] was shown to obtain sound joints in HEAs with reasonable mechanical properties. However, it should be noted that all of the studies were focused on welding of HEAs composed of non-refractory elements like $\mathrm{Co}, \mathrm{Fe}, \mathrm{Ni}$, etc. Meanwhile, there is no information in the literature on weldability of RHEAs. Therefore, in the present work we have explored the structure and mechanical properties of the $\mathrm{Ti}_{1.89} \mathrm{CrNbV}_{0.56} \mathrm{RHEA}$ butt joints obtained by LBW. This recently introduced RHEA [33] had a low density of $6.17 \mathrm{~g} / \mathrm{cm}^{3}$ and can be cold rolled to a high thickness reduction. The LBW technique was previously used successfully to join Ti alloys [34-39], and therefore, can be considered a proper welding method for the program Ti-rich RHEA.

The subject of the present work was to determine suitable parameters and process conditions for laser beam welding of the RHEA in order to achieve defect-free butt joints. Furthermore, the microstructure and mechanical properties of the welded joints were characterized. In particular, differences in microstructure between the weld and the base material were of interest.

\section{Materials and Methods}

Button-shaped ingots of the $\mathrm{Ti}_{1.89} \mathrm{CrNbV}_{0.56}$ alloy measured $\sim 60 \mathrm{~mm}$ in diameter and $\sim 12 \mathrm{~mm}$ in height were produced by arc melting in a low-pressure, high-purity argon atmosphere inside a water-cooled copper cavity. The purities of the alloying elements were no less than $99.9 \mathrm{wt}$. \%. The actual chemical composition of the alloy as per energy dispersive X-ray analysis (EDX) measurement with the scan area $\sim 1 \mathrm{~mm} \times 1 \mathrm{~mm}$ is presented in Table 1 .

Table 1. Chemical composition of the structural constituents of the $\mathrm{Ti}_{1.89} \mathrm{CrNbV}_{0.56}$ alloy, in at. \%.

\begin{tabular}{ccccc}
\hline Structural Constituent & $\mathbf{T i}$ & $\mathbf{C r}$ & $\mathbf{N b}$ & $\mathbf{V}$ \\
\hline Interdendrite & 39.8 & 24.7 & 24.2 & 11.3 \\
Alloy & 43.7 & 22.1 & 22.3 & 11.9 \\
\hline
\end{tabular}

Specimens for welding measured $40 \mathrm{~mm} \times 15 \mathrm{~mm} \times 2 \mathrm{~mm}$ were extracted from the as-cast ingots. Clear shiny surfaces (Ra-1.8 (according to ISO 1997)) on each side of the plates were obtained by mechanical polishing. Butt joint LBW was performed using an $8.0 \mathrm{~kW}$ continuous wave ytterbium fiber laser with a fiber optic ( $300 \mu \mathrm{m}$ core diameter, $300 \mathrm{~mm}$ focal length, $120 \mathrm{~mm}$ collimation lens and $750 \mu \mathrm{m}$ focus diameter). The wavelength of the laser was $1070 \mathrm{~nm}$ and the resulting beam parameter product was $10.6 \mathrm{~mm} \times$ mrad. Welding was performed in horizontal position $2 \mathrm{G}$ : the plane of the specimens was vertical, and the weld seam was horizontal. The weld coupon set-up was mounted on a linear motion unit, which was positioned in a chamber filled with argon protective gas (the Ar flow rate was $40 \mathrm{~L} / \mathrm{min}$ ). A heating device was used to pre-heat the specimens before welding in order 
to prevent the formation of cracks. Pre-heating temperatures of the specimens were measured by a thermocouple. Details of the LBW set-up can be found in [39].

The LBW process was performed using the following process parameters:

- $\quad$ The laser power of $2.5 \mathrm{~kW}$;

- The focus position of $0.0 \mathrm{~mm}$ above the specimen surface;

- $\quad$ The welding speed of $5 \mathrm{~m} / \mathrm{min}$;

- The pre-heating temperatures before LBW were $400{ }^{\circ} \mathrm{C}, 600{ }^{\circ} \mathrm{C}$, and $800{ }^{\circ} \mathrm{C}$; LBW at room temperature was also carried out for the sake of comparison.

The X-ray inspections were used to determine any inner imperfections in the welds, including porosity and cracks. The structure of the alloy was examined using X-ray diffraction (XRD) analysis, scanning (SEM), and transmission (TEM) electron microscopy. Specimens for SEM and XRD were prepared by careful mechanical polishing. XRD analysis was performed using a Rigaku diffractometer (Rigaku Corporation, Tokyo, Japan) with $\mathrm{CuK} \alpha$ radiation. SEM back-scattered electron (BSE) images were obtained using FEI Quanta 600 FEG microscope (FEI, Hillsboro, OR, USA) equipped with an EDX detector.

In addition, electron-backscattered diffraction (EBSD) analysis was performed (JEOL JSM-6490LV (JEOL, Akishima, Japan), EDAX TSL OIM (EDAX Inc, Mahwah, NJ, USA)). EBSD measurements were conducted at $30 \mathrm{kV}$, an emission current of $75 \mu \mathrm{A}$, a sample tilt angle of $70^{\circ}$, a working distance of $13 \mathrm{~mm}$ and a step size of $2.0 \mu \mathrm{m}$. The crystal orientation calculation was based on the generalized spherical harmonic expansion method, where triclinic sample symmetry could be assumed. The linear intercept method was used to measure the size of the grains.

The specimen for TEM analysis were prepared by conventional twin-jet electro-polishing of mechanically pre-thinned to $100 \mu \mathrm{m}$ foils, in a mixture of methanol $(600 \mathrm{~mL})$, butanol $(360 \mathrm{~mL})$, and perchloric acid $(60 \mathrm{~mL})$ at $-35^{\circ} \mathrm{C}$ and an applied voltage of $29.5 \mathrm{~V}$. TEM investigations were performed using JEOL JEM-2100 microscope (JEOL, Akishima, Japan) with an accelerating voltage of $200 \mathrm{kV}$.

Microhardness profiles across the joint were obtained using an automated Vickers hardness testing machine (Instron, Norwood, MA, USA). Nanohardness was determined via the Oliver and Pharr method [40] using Shimadzu DUH-211s Dynamic Ultra Micro Hardness Tester equipped with a Berkovich indenter (both-Shimadzu, Kyoto, Japan). At least ten indents, per structural constituent were performed with the maximum load of $50 \mathrm{mN}$ for $5 \mathrm{~s}$; the loading speed was $6.66 \mathrm{mN} / \mathrm{s}$.

Dog-bone-shaped tensile specimens, with a thickness of $0.5 \mathrm{~mm}$, were cut out using an electric discharge machine from the as-cast and welded specimens. The length and width of the gauge section were 10, and $2 \mathrm{~mm}$, respectively. In the welded specimens, the seam, located in the center of the gage, was perpendicular to the loading direction. Tensile tests were carried out on a $5-\mathrm{kN}$ electro-mechanic universal testing machine (Instron, Norwood, MA, USA) with a constant crosshead speed. The crosshead displacement was measured with a laser extensometer (Instron, Norwood, MA, USA). The tests were performed at $750{ }^{\circ} \mathrm{C}$, due to the low ductility of the alloy. The specimens were held at this temperature for $5 \mathrm{~min}$ before the onset of the test. The temperature was controlled by the thermocouple positioned at the center of the specimen gage. Three specimens, in each condition, were tested and characteristic stress-strain curves were shown.

The equilibrium phase diagram was constructed using Thermo-Calc (version 2019b) software and a TCHEA3 database (both-Thermo-Calc AB, Solna, Sweden).

\section{Results}

\subsection{Initial Microstructure}

The structure of the $\mathrm{Ti}_{1.89} \mathrm{CrNbV}_{0.56}$ alloy in the initial as-cast condition consisted of coarse bcc grains with noticeable dendritic segregations (Figure 1a). The average size of the bcc grains was $\sim 280 \mu \mathrm{m}$. However, both relatively fine $(\sim 100 \mu \mathrm{m})$ and very coarse $(\sim 500 \mu \mathrm{m})$ grains could also be 
found (Figure 1b). The grains had mostly an irregular shape with curved boundaries. As per chemical analysis the dendritic areas (light ones) were enriched with $\mathrm{Ti}$, while the inter-dendritic space (darker areas) were enriched with $\mathrm{Cr}$ and $\mathrm{Nb}$ (Table 1). In addition, a small amount ( 1\%) of lens-shaped second phase particles were found predominantly in the inter-dendritic areas (see the high magnification insert in Figure 1a). According to XRD (Figure 1c) and taking into account previous results for the same alloy [33], these particles can be identified as the C15 (cubic) Laves phase. Note that the presence of the C15 Laves particles with a similar morphology was recently revealed in the $\mathrm{Cr}_{10} \mathrm{Nb}_{30} \mathrm{Ti}_{30} \mathrm{Zr}_{30}$ alloy [41]. Small size of the particles (width less than $0.5 \mu \mathrm{m}$ ) did not allow identification of their chemical composition with SEM-EDX system reliably, however these particles were enriched with $\mathrm{Cr}$ and $\mathrm{Nb}$.

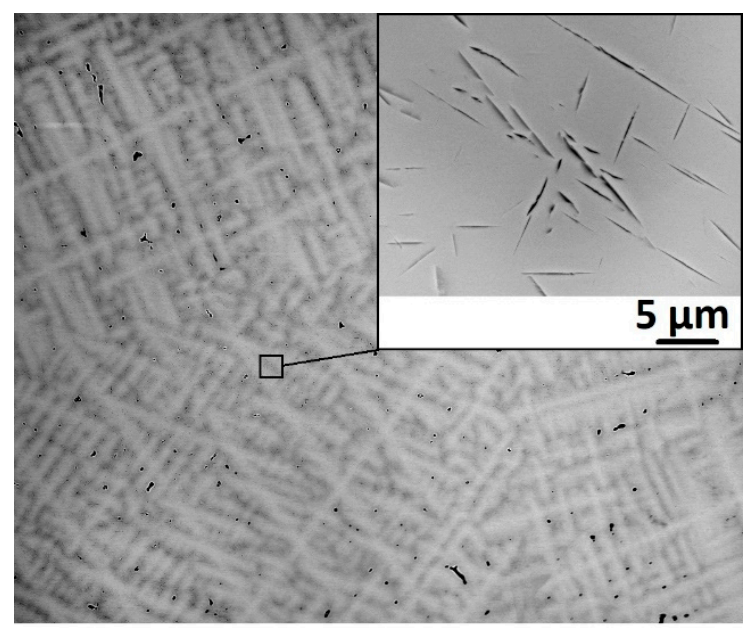

$200 \mu \mathrm{m}$

(a)

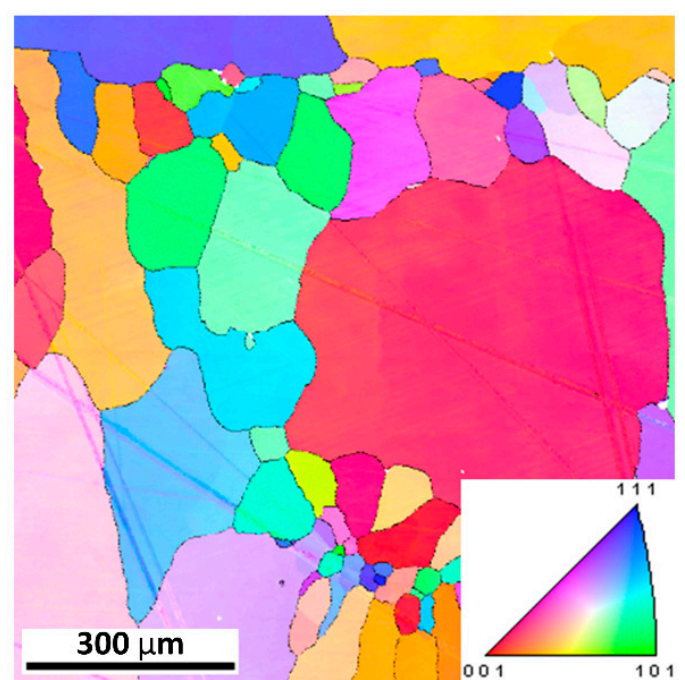

(b)

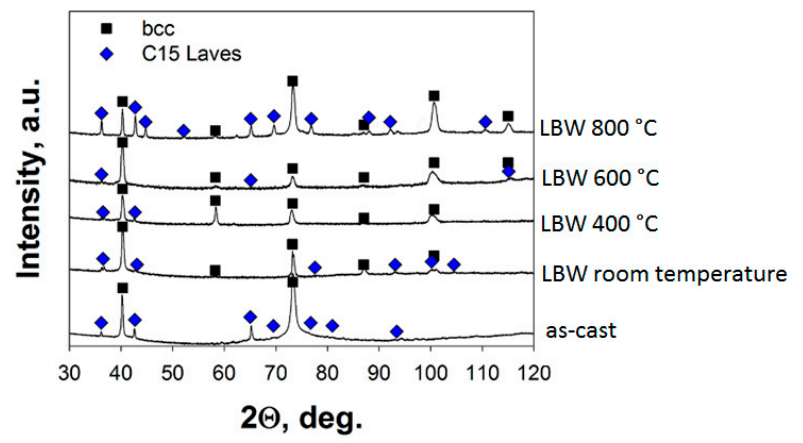

(c)

Figure 1. Structure of the $\mathrm{Ti}_{1.89} \mathrm{CrNbV}_{0.56}$ alloy in the initial as-cast condition: (a) SEM-BSE image; (b) crystal orientation map; (c) XRD pattern.

\subsection{Microstructure after Welding}

Figure 2 shows the results of X-ray inspections. Well-shaped homogeneous welds were achieved at room and at all pre-heating temperatures. Butt joints welded at room temperature showed several cracks perpendicular to the welding direction (Figure 2a). Specimens welded at $400{ }^{\circ} \mathrm{C}$ showed only a single crack in the central part of the specimen (Figure 2b). No cracks were identified after welding at $600^{\circ} \mathrm{C}$ or $800^{\circ} \mathrm{C}$ (Figure 2c,d). The present results show that the tendency to hot cracking decreases with an increase in the pre-heating temperature before welding. 
(a)

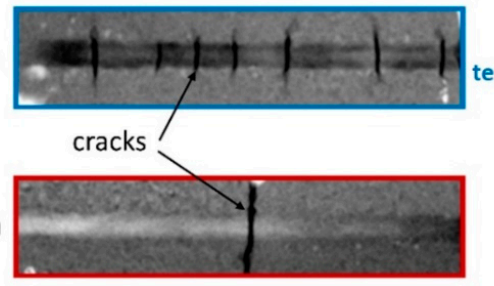

(c)

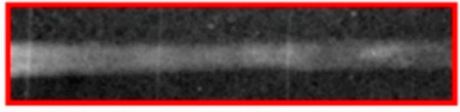

(d)

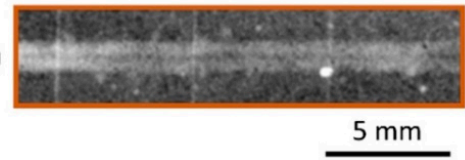

room emperature

$400^{\circ} \mathrm{C}$

$600^{\circ} \mathrm{C}$

$800^{\circ} \mathrm{C}$

Figure 2. Radiographs of butt joints welded at room temperature (a) or at different pre-heating temperatures; (b) $400{ }^{\circ} \mathrm{C}$; (c) $600{ }^{\circ} \mathrm{C}$, and (d) $800{ }^{\circ} \mathrm{C}$.

Grain structure of the welds obtained at different pre-heating temperatures was examined using EBSD technique (Figure 3); the dependence of the transversal size of the bcc grain on the pre-heating temperature is shown in Figure 4. In general, the microstructure of the welds is typical of metallic ingots [42]. After welding at room temperature, a columnar type structure was mainly formed in the weld (Figure 3a). The average width of the grains was $\sim 27 \mu \mathrm{m}$ (Figure 4); the long axis of the grains was oriented perpendicularly to the joint. At the fusion line between the fusion zone and the heat-affected zone fine $(\sim 10 \mu \mathrm{m})$, nearly equiaxed grains can be found. These grains were obviously formed at the initial stages of liquid metal solidification due to rapid heat transfer towards the "cold" base metal. Some coarse $(\sim 50 \mu \mathrm{m})$, nearly equiaxed grains were found at the center of the weld. An increase in the pre-heating temperature to $400{ }^{\circ} \mathrm{C}$ resulted in the formation of a more equiaxed structure (Figure $3 \mathrm{~b}$ ) with the average width of the columnar grains of $\sim 40 \mu \mathrm{m}$ (Figure 4 ). However, the microstructure had the same morphology typical of metallic ingots: Fine and coarse equiaxed grains at the fusion line between the fusion zone and heat-affected zone, and in the center of the weld, respectively, separated by a columnar grains region. Further increase in the pre-heating temperature during welding resulted in some coarsening of the microstructure (Figure $3 c, d$ ). For example, the average width of the columnar grains was $\sim 50 \mu \mathrm{m}$ or $\sim 70 \mu \mathrm{m}$ after welding at $600^{\circ} \mathrm{C}$ or $800^{\circ} \mathrm{C}$, respectively (Figure 4 ).

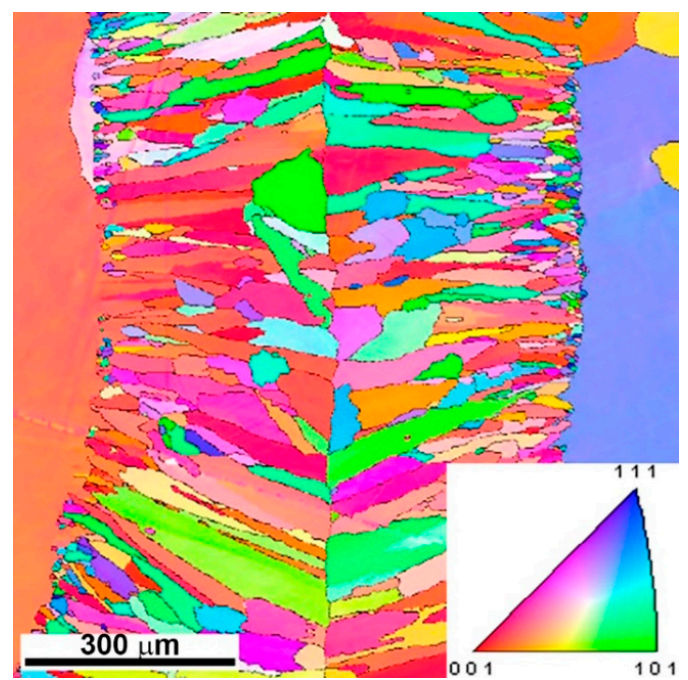

(a)

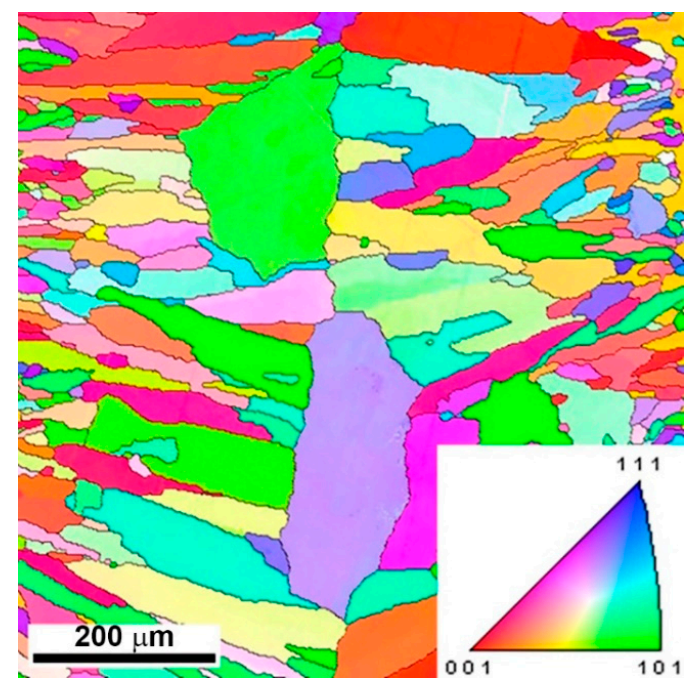

(b)

Figure 3. Cont. 


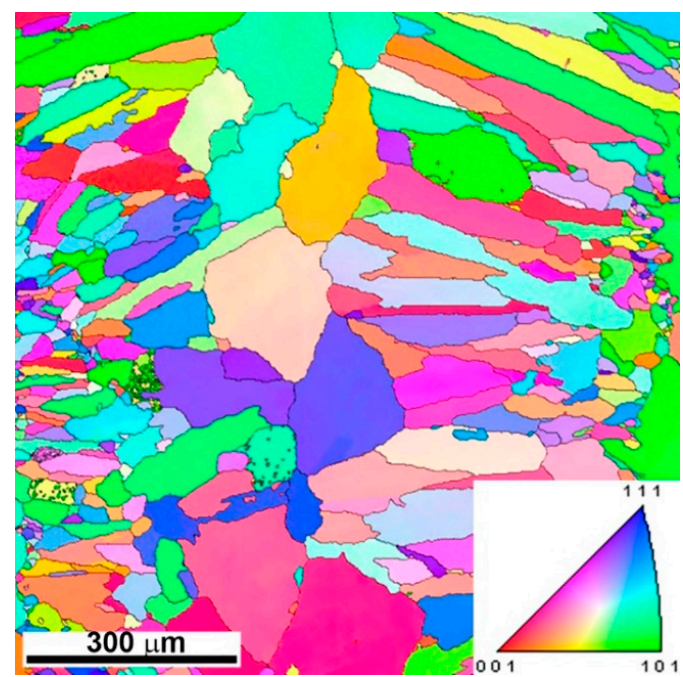

(c)

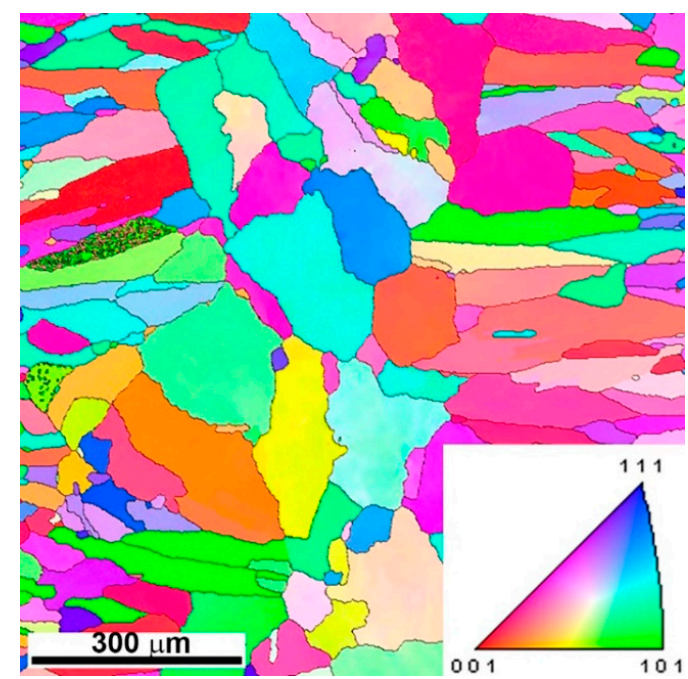

(d)

Figure 3. Crystal orientation maps of butt joint cross-section (seams are vertical in all cases) obtained by laser beam welding (LBW) with different pre-heating temperatures: (a) Room temperature; (b) $400{ }^{\circ} \mathrm{C}$; (c) $600{ }^{\circ} \mathrm{C}$; (d) $800{ }^{\circ} \mathrm{C}$.

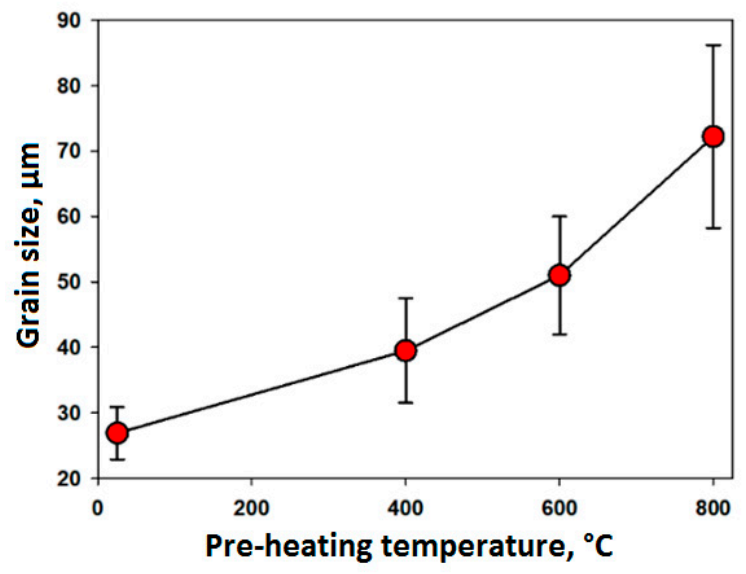

Figure 4. Dependence of the transversal size of the columnar grains inside the welds on the pre-heating temperature.

SEM images of the welding zone are presented in Figure 5. One can see that the dendritic structure survived after welding. However, the width of the dendrite arms and the distance between them gradually increased with the pre-heating temperature, due to lower cooling rates of the melted alloy during solidification. In addition to the changes in the scale of dendrite structure, the pre-heating temperature affected the phase structure of the alloy in the weld. No second phase particles were detected in the samples welded at room temperature or $400{ }^{\circ} \mathrm{C}$ (see high magnification inserts in Figure 5a,b). An increase in the pre-heating temperature resulted in the Laves phase particles precipitation predominantly nearby the inter-dendritic areas (Figure $5 c, d$ ). The size and fraction of the particles also increased with the pre-heating temperature. Note that the XRD patters showed the presence of the Laves phase in all conditions (Figure 1c). However, these particles were most likely located in the base material (see below). 


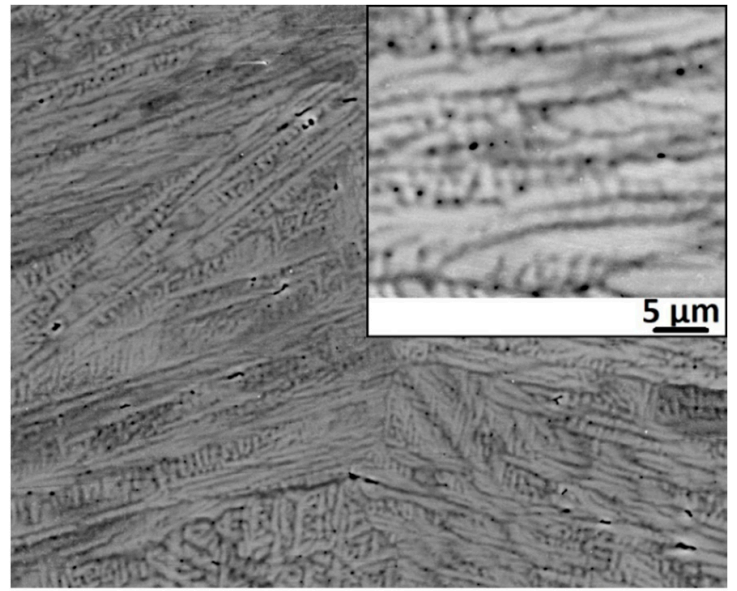

$25 \mu \mathrm{m}$

(a)

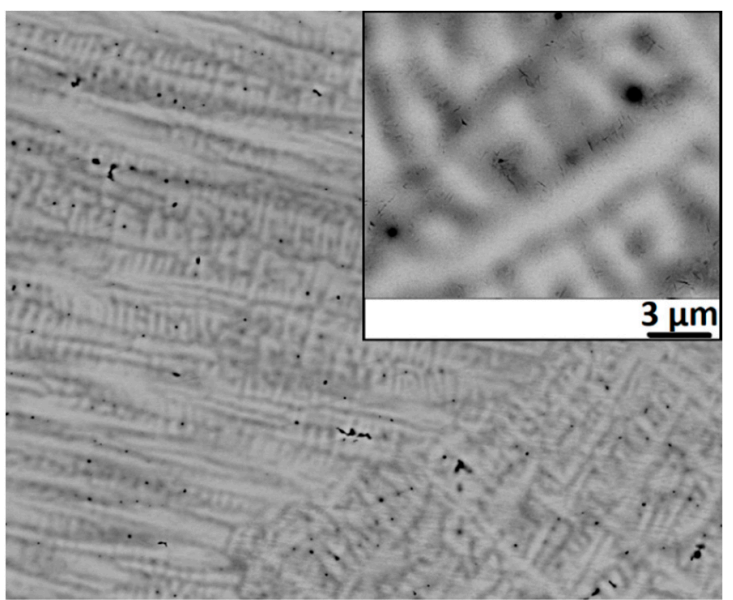

$25 \mu \mathrm{m}$

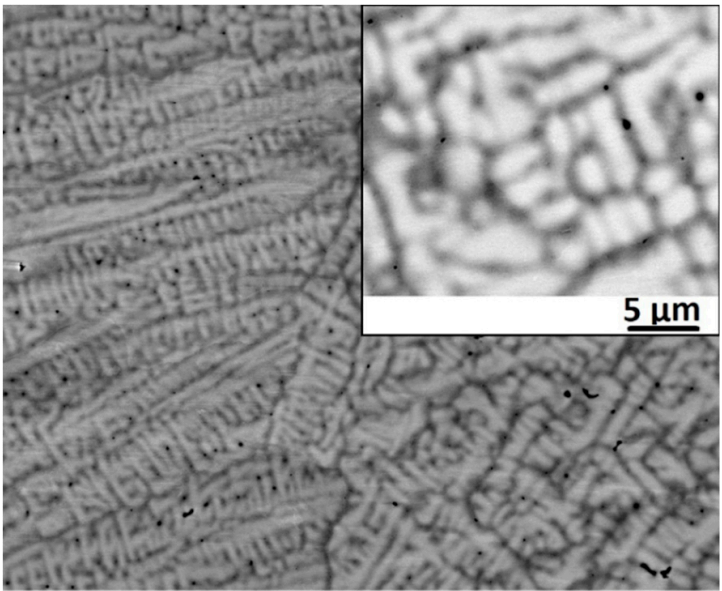

$25 \mu \mathrm{m}$

(b)

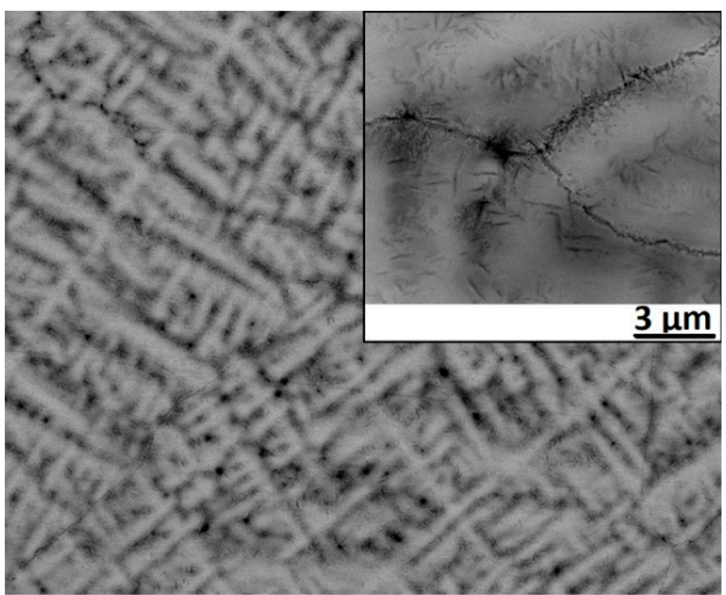

$25 \mu \mathrm{m}$

(c)

(d)

Figure 5. SEM-BSE images of the welding zone after LBW at different pre-heating temperatures:

(a) room temperature; (b) $400{ }^{\circ} \mathrm{C}$; (c) $600{ }^{\circ} \mathrm{C}$; (d) $800{ }^{\circ} \mathrm{C}$.

Figure 6 shows SEM-BSE images of the base material taken far enough $(\sim 5 \mathrm{~mm})$ from the welds. In the specimens welded at $\mathrm{T} \leq 400{ }^{\circ} \mathrm{C}$ (Figure $6 \mathrm{a}, \mathrm{b}$ ) the microstructure was nearly identical to that in the initial as-cast state (Figure 1a) and was presented by the dendritic segregations with the embedded lens-shaped Laves particles in the bcc coarse-grained matrix. The microstructures of the specimens welded at $600{ }^{\circ} \mathrm{C}$ or $800^{\circ} \mathrm{C}$ (Figure $6 \mathrm{c}, \mathrm{d}$ ) contained in addition fine dark precipitates located nearby the lens-shaped Laves particles. The fraction of these "additional" particles increased considerably with an increase in the pre-heating temperature from $600{ }^{\circ} \mathrm{C}$ to $800{ }^{\circ} \mathrm{C}$. Further TEM investigation revealed that these particles were also in the $\mathrm{C} 15$ Laves phase (Figure 7). 


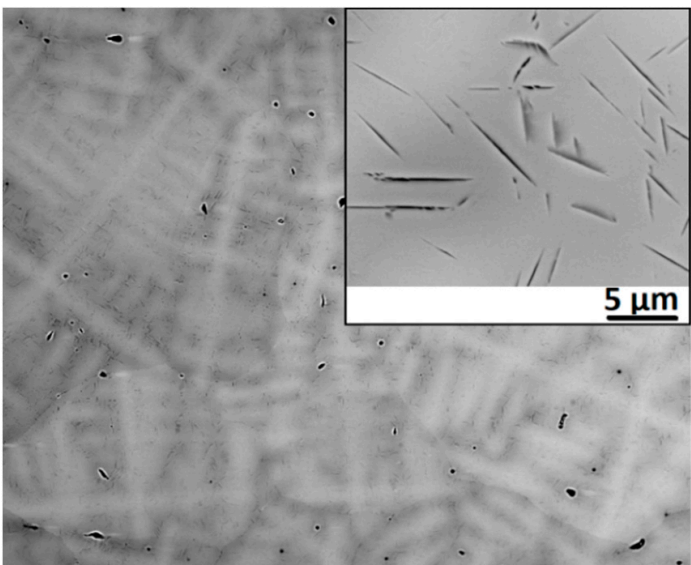

$100 \mu \mathrm{m}$

(a)

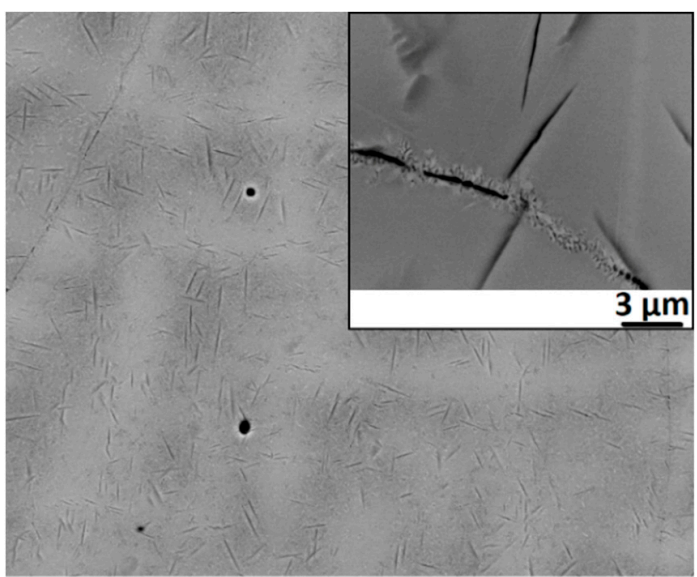

$25 \mu \mathrm{m}$

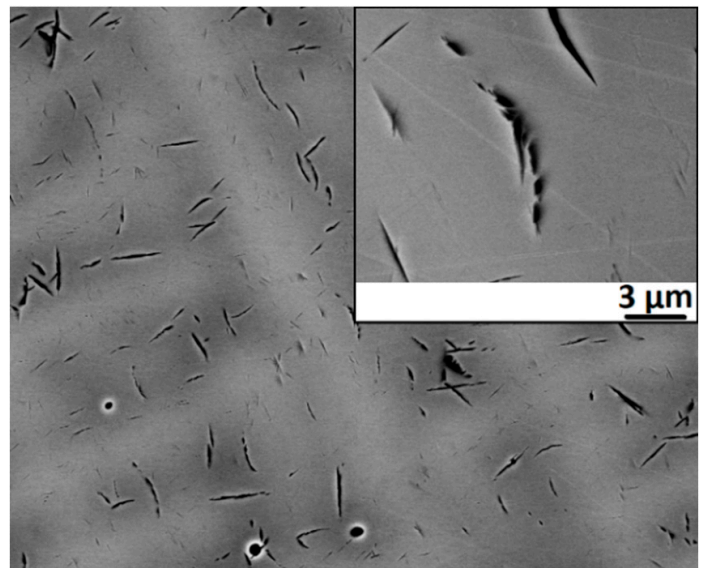

$25 \mu \mathrm{m}$

(b)

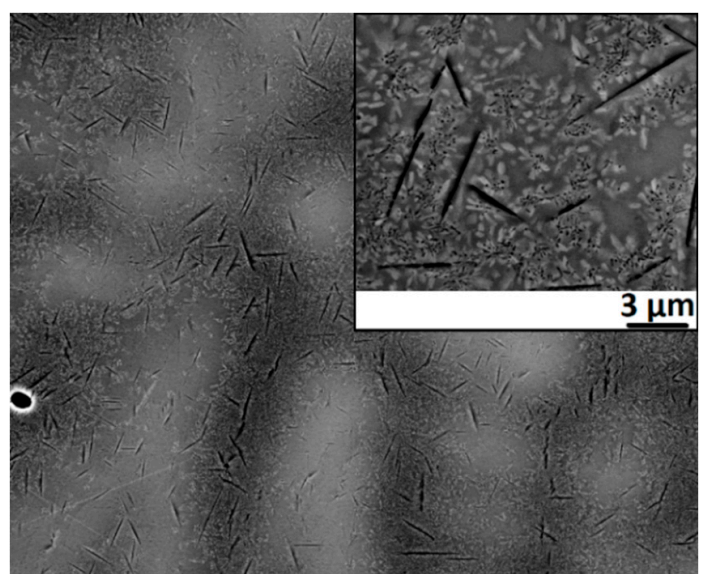

$25 \mu \mathrm{m}$

(d)

Figure 6. SEM-BSE images of the base material in specimens subjected to LBW at different pre-heating temperatures: (a) room temperature; (b) $400{ }^{\circ} \mathrm{C}$; (c) $600{ }^{\circ} \mathrm{C}$; (d) $800{ }^{\circ} \mathrm{C}$.

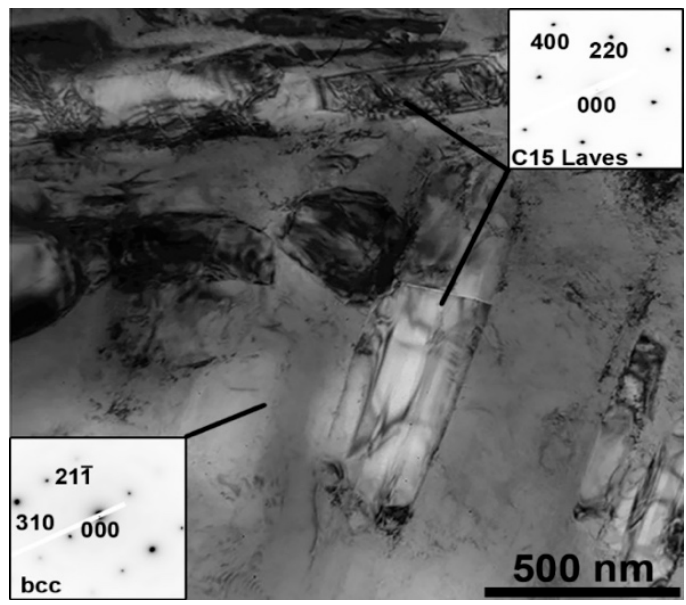

Figure 7. TEM bright-field image of the base material in the specimen after LBW at the pre-heating temperature of $800{ }^{\circ} \mathrm{C}$. 


\subsection{Mechanical Properties}

Figure 8 shows microhardness profiles across the weld obtained at room (Figure 8a) or elevated pre-heating temperatures (Figure $8 \mathrm{~b}$ ). There is no significant variation in the hardness profiles depending on the measurement location (radiation exposure side, half-thickness, or weld root side) after welding at room temperature (Figure 8a). The hardness increases from $475 \mathrm{HV}$ in the base material to $550 \mathrm{HV}$ in the fusion zone after welding at room temperature. An increase in the pre-heating temperature during welding slightly decreased the hardness of the base material until it reached 450 $\mathrm{HV}$ after welding at $800^{\circ} \mathrm{C}$. However, the pre-heating temperature had a much more pronounced effect on the fusion zone hardness. The differences between the base material and fusion zone hardness became lower with an increase in the pre-heating temperature, and no hardness gradient can be detected after welding at $800{ }^{\circ} \mathrm{C}$ (Figure 8 b).

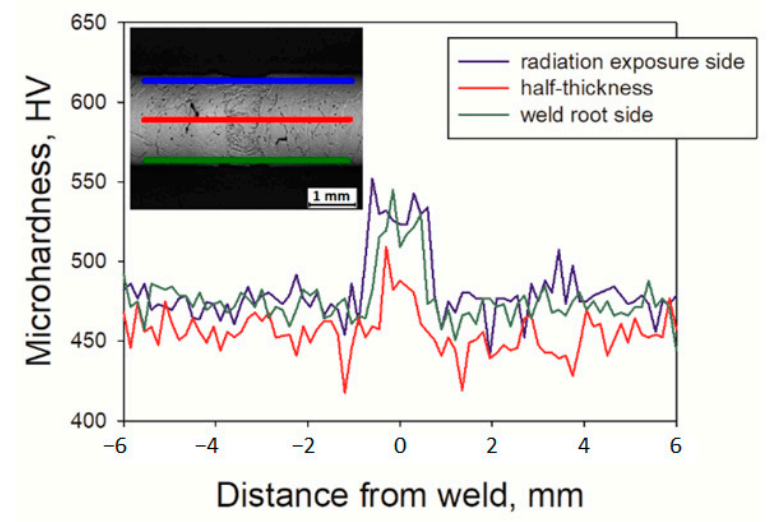

(a)

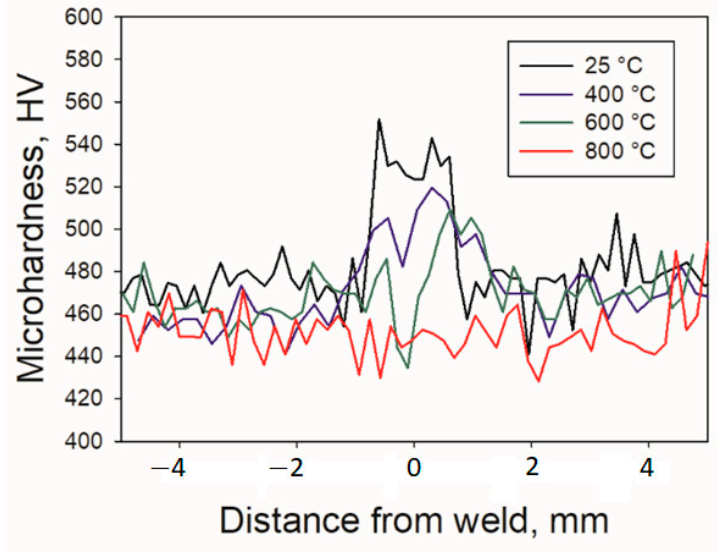

(b)

Figure 8. Microhardness profiles across the weld: (a) at room temperature along radiation exposure side (blue line), half-thickness (red line) and weld root side (green line); (b) at different pre-heating temperature before welding along the half-thickness line.

To get a better understanding of the welding conditions effect on the mechanical properties of the alloy, tensile tests were performed. Tensile stress-strain curves obtained at $750{ }^{\circ} \mathrm{C}$ for the as-cast and laser beam welded at $400-800^{\circ} \mathrm{C}$ specimens are shown in Figure 9. Note that the specimens welded at room temperature were not tested, since the seams contained numerous cracks (Figure 2a) and therefore could not show suitable properties. The as-cast alloy also fractured in the elastic region at $250 \mathrm{Mpa}$ without any tensile ductility (Table 2). After LBW at $400^{\circ} \mathrm{C}$, the alloy demonstrated almost the same behavior. An increase in the pre-heating temperature before welding to $600{ }^{\circ} \mathrm{C}$ resulted in a drastic decrease in the fracture stress to $45 \mathrm{Mpa}$. However, after $800^{\circ} \mathrm{C}$ the alloy showed reasonable ductility of $\sim 10 \%$. The yield strength of this condition was $265 \mathrm{Mpa}$; after a short hardening stage, and by reaching the ultimate tensile strength of $285 \mathrm{Mpa}$, an extensive softening stage associated with strain localization was observed. In all cases, fractures occurred in the base material. 


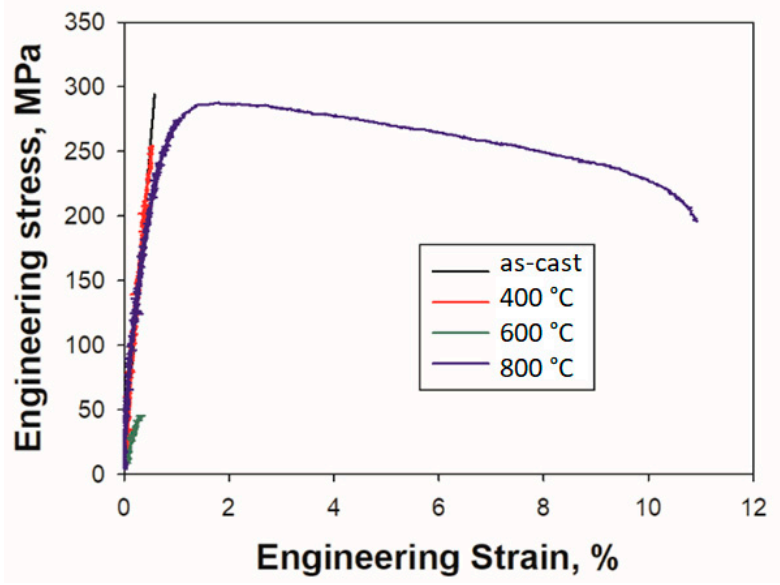

Figure 9. Engineering stress-strain curves of the $\mathrm{Ti}_{1.89} \mathrm{NbCrV}_{0.56}$ alloy tensioned at $750{ }^{\circ} \mathrm{C}$ in the as-cast state and after LBW at 400,600 or $800{ }^{\circ} \mathrm{C}$.

Table 2. Mechanical properties (YS — yield strength, UTS — ultimate tensile strength, FS—fracture stress, $\delta$-elongation to fracture) of the $\mathrm{Ti}_{1.89} \mathrm{NbCrV}_{0.56}$ alloy obtained by tensile tests at $750{ }^{\circ} \mathrm{C}$ in the as-cast state and after LBW at 400,600 or $800{ }^{\circ} \mathrm{C}$.

\begin{tabular}{cccc}
\hline Condition & YS, Mpa & UTS (or FS), Mpa & $\boldsymbol{\delta}, \%$ \\
\hline As-cast & - & $(250)$ & 0 \\
LBW $400^{\circ} \mathrm{C}$ & - & $(255)$ & 0 \\
LBW $600^{\circ} \mathrm{C}$ & - & $(45)$ & 0 \\
LBW $800^{\circ} \mathrm{C}$ & 265 & 285 & 10.4 \\
\hline
\end{tabular}

Fracture surfaces of laser beam welded specimens at $400{ }^{\circ} \mathrm{C}$ or $800{ }^{\circ} \mathrm{C}$ after tensile tests were quite different (Figure 10). At the lower pre-heating temperature during welding, a typical brittle fracture with cleavage planes and river pattern on some facets, was observed. Secondary cracks were formed along some grain boundaries. At the higher pre-heating temperature $\left(800^{\circ} \mathrm{C}\right)$ the character of fracture became more ductile; the fracture surface was consisted of relatively small $(\sim 5 \mu \mathrm{m})$ dimples due to void coalescence.

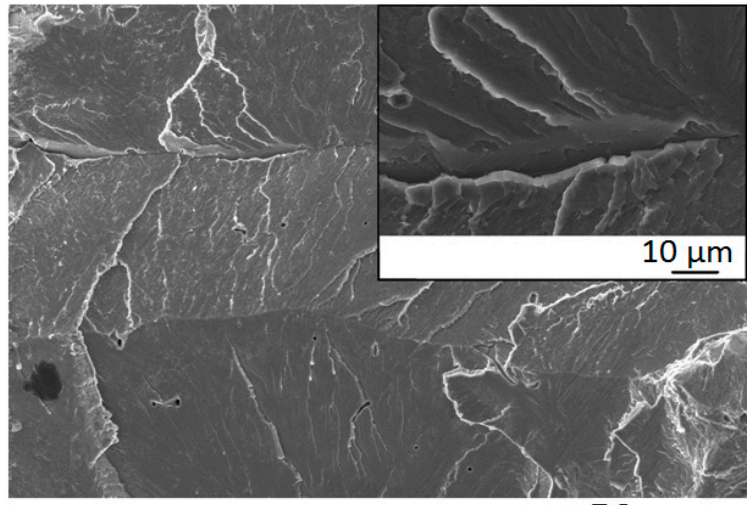

$50 \mu \mathrm{m}$

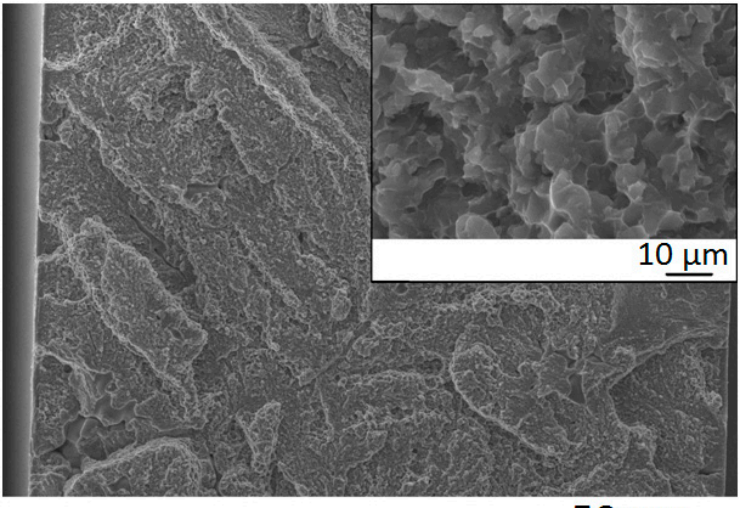

$50 \mu \mathrm{m}$

(a)

(b)

Figure 10. Fracture surfaces of the tensile specimens after LBW at different pre-heating temperatures: (a) $400{ }^{\circ} \mathrm{C}$; (b) $800{ }^{\circ} \mathrm{C}$.

\section{Discussion}

In this work, a butt joint of the $\mathrm{Ti}_{1.89} \mathrm{CrNbV}_{0.56}$ RHEA, using laser beam welding, was successfully produced for the first time. Due to a high melting temperature and brittleness of the material, LBW was 
performed at different pre-heating temperatures from room temperature to $800{ }^{\circ} \mathrm{C}$ to prevent the formation of hot cracks. Apparently, the pre-heating temperature affected both the microstructure and mechanical properties of the welded specimens significantly.

The initial, as-cast microstructure was quite heterogeneous and consisted of coarse bcc matrix grains with the lens-shaped Laves phase particles (Figure 1). LBW has obviously affected the morphology of the bcc grains in the welding zone (WZ) (Figure 3). The grains became elongated in the direction normal to the laser beam, and the width of these grains increased with pre-heating temperature, most likely due to enhanced mobility of grain boundaries at higher pre-heating temperatures. In addition, LBW at the lower pre-heating temperatures (room temperature and $400{ }^{\circ} \mathrm{C}$ ) has resulted in the Laves phase particles disappearance (Figure $5 a, b$ ). The formation of these particles in the alloy deserves a more detailed analysis. The equilibrium phase diagram for the alloy constructed by the Thermo-Calc software is presented in Figure 11.

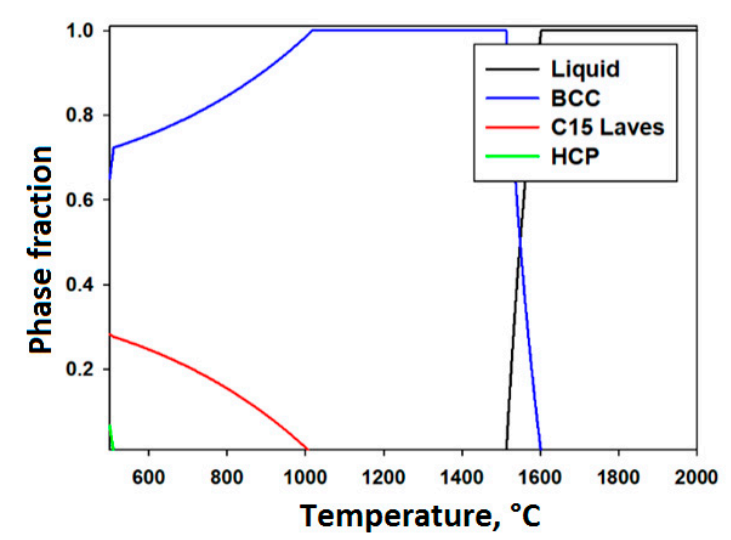

Figure 11. Phase diagram of the $\mathrm{Ti}_{1.89} \mathrm{NbCrV}_{0.56}$ alloy constructed using the Thermo-Calc software (BCC—body-centered cubic structure; $\mathrm{HCP}$ - hexagonal close packed structure).

The alloy is supposed to have a single bcc phase structure starting from the solidus temperature of $\sim 1500{ }^{\circ} \mathrm{C}$ till $\sim 1000{ }^{\circ} \mathrm{C}$; the latter corresponds to the onset of the Cr-rich $\mathrm{C} 15$ Laves phase precipitation. The fraction of the Laves phase increased with a decrease in temperature. Finally, at $\mathrm{T} \approx 500{ }^{\circ} \mathrm{C}$ a Ti-rich hcp phase precipitated. The presence of the Laves phase in the initial as-cast condition can be most probably associated with a rather low cooling rate of relatively big ingots of the alloy that was not enough to "freeze" the high-temperature single-phase structure. In turn, faster cooling rates of the alloy, during the welded material solidification, prevented the formation of the Laves particles in the case of LBW at room temperature or $400{ }^{\circ} \mathrm{C}$. During welding at higher pre-heating temperatures, the cooling rate is slower thereby allowing the Laves particles precipitation.

Also, annealing at $800^{\circ} \mathrm{C}$ resulted in the precipitation of "additional" Laves particles in the base material after welding at pre-heating temperature of $600^{\circ} \mathrm{C}$ or $800^{\circ} \mathrm{C}$. The formation of the particles can be attributed to the decomposition of the supersaturated bcc solid solution during holding at elevated temperatures (Figure 11). Note that the particles precipitated in the inter-dendritic areas were observed mainly nearby the coarser particles, inherited from the as-cast condition. The Laves phase in this alloy is supposed to be composed of $\mathrm{Cr}$ and $\mathrm{Nb}$ predominantly [33] and, therefore, the "additional" particles formed in the inter-dendritic areas which were rich in these elements (Table 1), similarly to the Laves phase particles formation in the $\mathrm{NbCrMo}_{0.5} \mathrm{Ta}_{0.5} \mathrm{TiZr}$ alloy [43].

Mechanical properties of the $\mathrm{Ti}_{1.89} \mathrm{NbCrV}_{0.56}$ alloy were found to be strongly sensitive to the welding conditions. A noticeable increase in the fusion zone hardness, as well as the variation in the hardness with the temperature during welding (Figure $8 b$ ), can be attributed to the bcc matrix grain size as a function of pre-heating temperature (Figure 4). The relationship between the average hardness and average grain size in the fusion zone shown in Figure 12 suggests that the Hall-Petch mechanism is active. 


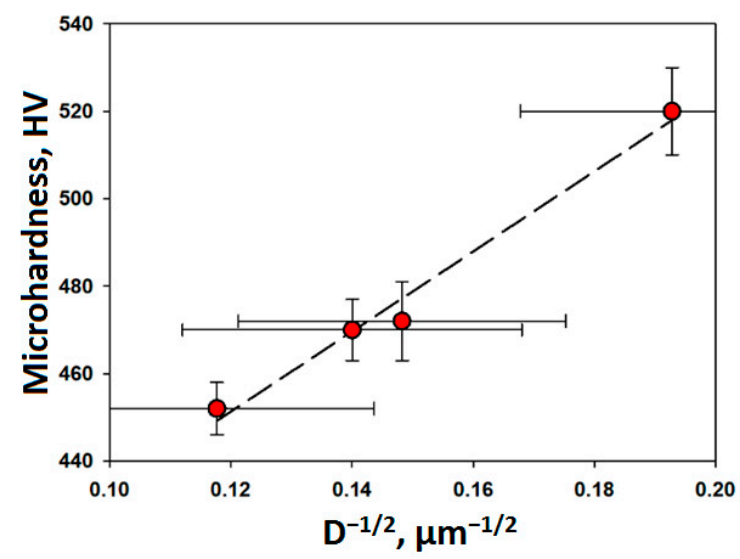

Figure 12. Relationship between the hardness and grain size in the fusion zone.

Due to the higher hardness of the weld, welded specimens fractured in the base material section during tensile tests. This type of behavior was observed earlier in other welded HEAs [44]. However, the welding conditions strongly influenced on tensile behavior; for example, specimens welded at $\mathrm{T} \leq 600{ }^{\circ} \mathrm{C}$ exhibited brittle fracture even at $750{ }^{\circ} \mathrm{C}$ while the alloy welded at $800{ }^{\circ} \mathrm{C}$ showed reasonable ductility (Figure 9, Table 2). One of the reasons for the increased ductility can be associated with the formation of a less defect structure (in terms of cracks) with an increase in the pre-heating temperature before welding (Figure 2).

The "additional" Laves particles precipitation after welding at $800{ }^{\circ} \mathrm{C}$ can also provoke an increase in ductility. It is generally believed that the second phase particles precipitation should result in strengthening. However, in the present case nano-hardness of the particles-containing areas (480 HV) was found to be lower than that of the particle-free zone $(560 \mathrm{HV})$ after welding at $800^{\circ} \mathrm{C}$. This result can most likely be related to (i) lower solid solution hardening of the bcc matrix due to depletion in $\mathrm{Cr}$ and $\mathrm{Nb}[11,33]$ and (ii) low (er) hardness of the Laves phase itself [33]. That is why the Laves phase particles precipitation in the present alloy resulted in both some softening and an increase in ductility after welding at $800^{\circ} \mathrm{C}$. It should be also noted, that the size of the facets in Figure 10b is correlated with the size of precipitation-free areas (Figure $5 \mathrm{~d}$ ) thereby suggesting that the more ductile behavior can be associated with a temporary crack arrest in these $\mathrm{Cr}$ and $\mathrm{Nb}$ depleted regions.

The obtained results demonstrate for the first time the possibility to produce sound butt joints of the $\mathrm{Ti}_{1.89} \mathrm{NbCrV}_{0.56}$ RHEA by LBW, which is an important step toward potential practical applications of this new class of metallic alloys. However, the present study also emphasized the importance of LBW process parameters (particularly pre-heating temperature) to obtain good results, which is quite different from the transition metals HEAs [27-32,44,45]. Given the wide range of the available RHEAs compositions [7], specific attention should be paid to select proper welding conditions for each individual alloy.

\section{Conclusions}

In this work, laser beam welding, at different pre-heating temperatures, was successfully used to produce butt joints of the $\mathrm{Ti}_{1.89} \mathrm{NbCrV}_{0.56}$ refractory high entropy alloy. The following conclusions were drawn:

1. The as-cast $\mathrm{Ti}_{1.89} \mathrm{NbCrV}_{0.56}$ alloy had a coarse-grained bcc structure with a small amount of lens-shaped $\mathrm{C} 15$ Laves phase particles. Welding at room temperature or using the pre-heating temperature of $400{ }^{\circ} \mathrm{C}$ did not result in the formation of the Laves phase particles in the seams. However, these particles were found after welding with the pre-heating temperature of $600{ }^{\circ} \mathrm{C}$ or $800^{\circ} \mathrm{C}$. Newly crystallized bcc grains in the welds were mostly elongated; their thickness increased with an increase in the pre-heating temperature. The structure of the base material did not change noticeably after welding except for the "additional" Laves particles precipitation 
after soaking at 600 or $800{ }^{\circ} \mathrm{C}$ during LBW. Cracks were observed in the weld after LBW at room temperature or at $400^{\circ} \mathrm{C}$.

2. Specimens welded at the pre-heating temperature of $800{ }^{\circ} \mathrm{C}$ demonstrated reasonable tensile ductility at $750{ }^{\circ} \mathrm{C}$; welding at the lower pre-heating temperatures resulted in brittle fracture during tension. Fracture in all cases occurred in the base material. The hardness of the weld was higher than that of the base material due to the bcc grains refinement.

Author Contributions: Conceptualization, S.Z., N.S., N.K.; methodology, N.K., G.S., V.V.; validation, E.P., N.K.; formal analysis, N.K., N.S.; investigation, E.P., N.Y., V.V., R.D.; resources, G.S., N.K.; data curation, E.P.; writing-original draft preparation, N.S.; writing-review and editing, S.Z., N.K.; visualization, E.P., N.Y.; supervision, N.K., G.S.; project administration, S.Z.; funding acquisition, G.S.

Funding: This research was funded by the Russian Science Foundation Grant no. 19-79-30066.

Acknowledgments: The authors are grateful to the personnel of the Joint Research Center, Technology and Materials, Belgorod National Research University, for their assistance with the instrumental analysis.

Conflicts of Interest: The authors declare no conflict of interest.

\section{References}

1. Perepezko, J.H. Materials science. The hotter the engine, the better. Science 2009, 326, 1068-1069. [CrossRef] [PubMed]

2. Yeh, J.W.; Chen, S.K.; Lin, S.J.; Gan, J.Y.; Chin, T.S.; Shun, T.T.; Tsau, C.H.; Chang, S.Y. Nanostructured high-entropy alloys with multiple principal elements: Novel alloy design concepts and outcomes. Adv. Eng. Mater. 2004, 6, 299-303. [CrossRef]

3. Miracle, D.B.; Senkov, O.N. A critical review of high entropy alloys and related concepts. Acta Mater. 2017, 122, 448-511. [CrossRef]

4. Gorsse, S.; Miracle, D.B.; Senkov, O.N. Mapping the world of complex concentrated alloys. Acta Mater. 2017, 135, 177-187. [CrossRef]

5. Gludovatz, B.; Hohenwarter, A.; Catoor, D.; Chang, E.H.; George, E.P.; Ritchie, R.O. A fracture-resistant high-entropy alloy for cryogenic applications. Science 2014, 345, 1153-1158. [CrossRef]

6. Li, Z.; Pradeep, K.G.; Deng, Y.; Raabe, D.; Tasan, C.C. Metastable high-entropy dual-phase alloys overcome the strength-ductility trade-off. Nature 2016, 534, 227-230. [CrossRef]

7. Senkov, O.N.; Miracle, D.B.; Chaput, K.J.; Couzinie, J.-P. Development and exploration of refractory high entropy alloys-A review. J. Mater. Res. 2018, 33, 3092-3128. [CrossRef]

8. Senkov, O.N.; Wilks, G.B.; Miracle, D.B.; Chuang, C.P.; Liaw, P.K. Refractory high-entropy alloys. Intermetallics 2010, 18, 1758-1765. [CrossRef]

9. Senkov, O.N.; Wilks, G.B.; Scott, J.M.; Miracle, D.B. Mechanical properties of $\mathrm{Nb}_{25} \mathrm{Mo}_{25} \mathrm{Ta}_{25} \mathrm{~W}_{25}$ and $\mathrm{V}_{20} \mathrm{Nb}_{20} \mathrm{Mo}_{20} \mathrm{Ta}_{20} \mathrm{~W}_{20}$ refractory high entropy alloys. Intermetallics 2011, 19, 698-706. [CrossRef]

10. Senkov, O.N.; Senkova, S.V.; Woodward, C.; Miracle, D.B. Low-density, refractory multi-principal element alloys of the Cr-Nb-Ti-V-Zr system: Microstructure and phase analysis. Acta Mater. 2013, 61, 1545-1557. [CrossRef]

11. Senkov, O.N.; Senkova, S.V.; Miracle, D.B.; Woodward, C. Mechanical properties of low-density, refractory multi-principal element alloys of the Cr-Nb-Ti-V-Zr system. Mater. Sci. Eng. A 2013, 565, 51-62. [CrossRef]

12. Senkov, O.N.; Senkova, S.V.; Woodward, C.F. Effect of aluminum on the microstructure and properties of two refractory high-entropy alloys. Acta Mater. 2014, 68, 214-228. [CrossRef]

13. Senkov, O.N.; Woodward, C.; Miracle, D.B. Microstructure and properties of aluminum-containing refractory high-entropy alloys. JOM 2014, 66, 2030-2042. [CrossRef]

14. Stepanov, N.D.; Shaysultanov, D.G.; Salishchev, G.A.; Tikhonovsky, M.A. Structure and mechanical properties of a light-weight AlNbTiV high entropy alloy. Mater. Lett. 2015, 142, 153-155. [CrossRef]

15. Stepanov, N.D.; Yurchenko, N.Y.; Skibin, D.V.; Tikhonovsky, M.A.; Salishchev, G.A. Structure and mechanical properties of the AlCrxNbTiV (x=0, 0.5, 1, 1.5) high entropy alloys. J. Alloys Compd. 2015, 652, 266-280. [CrossRef]

16. Stepanov, N.D.; Yurchenko, N.Y.; Panina, E.S.; Tikhonovsky, M.A.; Zherebtsov, S.V. Precipitation-strengthened refractory Al0.5CrNbTi2V0.5 high entropy alloy. Mater. Lett. 2017, 188, 162-164. [CrossRef] 
17. Yurchenko, N.Y.; Stepanov, N.D.; Zherebtsov, S.V.; Tikhonovsky, M.A.; Salishchev, G.A. Structure and mechanical properties of $\mathrm{B} 2$ ordered refractory $\mathrm{AlNbTiVZr}_{\mathrm{x}}(\mathrm{x}=0-1.5)$ high-entropy alloys. Mater. Sci. Eng. A 2017, 704, 82-90. [CrossRef]

18. Senkov, O.N.; Jensen, J.K.; Pilchak, A.L.; Miracle, D.B.; Fraser, H.L. Compositional variation effects on the microstructure and properties of a refractory high-entropy superalloy AlMo0.5NbTa0.5TiZr. Mater. Des. 2018, 139, 498-511. [CrossRef]

19. Senkov, O.N.; Rao, S.; Chaput, K.J.; Woodward, C. Compositional effect on microstructure and properties of NbTiZr-based complex concentrated alloys. Acta Mater. 2018, 151, 201-215. [CrossRef]

20. Chen, H.; Kauffmann, A.; Gorr, B.; Schliephake, D.; Seemüller, C.; Wagner, J.N.; Christ, H.-J.; Heilmaier, M. Microstructure and mechanical properties at elevated temperatures of a new Al-containing refractory high-entropy alloy Nb-Mo-Cr-Ti-Al. J. Alloys Compd. 2016, 661, 206-215. [CrossRef]

21. Xu, Z.Q.; Cheng, X.W.; Wang, M.; Chen, Y.W.; Tan, Y.D.; Ma, Z.L. Design of novel low-density refractory high entropy alloys for high temperature applications. Mater. Sci. Eng. A 2019, 755, 318-322. [CrossRef]

22. Miracle, D.; Majumdar, B.; Wertz, K.; Gorsse, S. New strategies and tests to accelerate discovery and development of multi-principal element structural alloys. Scr. Mater. 2017, 127, 195-200. [CrossRef]

23. Senkov, O.N.; Semiatin, S.L. Microstructure and properties of a refractory high-entropy alloy after cold working. J. Alloys Compd. 2015, 649, 1110-1123. [CrossRef]

24. Senkov, O.N.; Pilchak, A.L.; Semiatin, S.L. Effect of cold deformation and annealing on the microstructure and tensile properties of a HfNbTaTiZr refractory high entropy alloy. Metall. Mater. Trans. A 2018, 49, 2876-2892. [CrossRef]

25. Lilensten, L.; Couzinié, J.-P.; Bourgon, J.; Perrière, L.; Dirras, G.; Prima, F.; Guillot, I. Design and tensile properties of a bcc Ti-rich high-entropy alloy with transformation-induced plasticity. Mater. Res. Lett. 2017, 5, 110-116. [CrossRef]

26. Sheikh, S.; Shafeie, S.; Hu, Q.; Ahlström, J.; Persson, C.; Veselý, J.; Zýka, J.; Klement, U.; Guo, S. Alloy design for intrinsically ductile refractory high-entropy alloys. J. Appl. Phys. 2016, 120, 164902. [CrossRef]

27. Wu, Z.; David, S.A.; Feng, Z.; Bei, H. Weldability of a high entropy CrMnFeCoNi alloy. Scr. Mater. 2016, 124, 81-85. [CrossRef]

28. Wu, Z.; David, S.A.; Leonard, D.N.; Feng, Z.; Bei, H. Microstructures and mechanical properties of a welded CoCrFeMnNi high-entropy alloy. Sci. Technol. Weld. Join. 2018, 23, 585-595. [CrossRef]

29. Zhu, Z.G.; Sun, Y.F.; Ng, F.L.; Goh, M.H.; Liaw, P.K.; Fujii, H.; Nguyen, Q.B.; Xu, Y.; Shek, C.H.; Nai, S.M.L.; et al. Friction-stir welding of a ductile high entropy alloy: Microstructural evolution and weld strength. Mater. Sci. Eng. A 2018, 711, 524-532. [CrossRef]

30. Zhu, Z.G.; Sun, Y.F.; Goh, M.H.; Ng, F.L.; Nguyen, Q.B.; Fujii, H.; Nai, S.M.L.; Wei, J.; Shek, C.H. Friction stir welding of a CoCrFeNiAl0.3 high entropy alloy. Mater. Lett. 2017, 205, 142-144. [CrossRef]

31. Kashaev, N.; Ventzke, V.; Stepanov, N.; Shaysultanov, D.; Sanin, V.; Zherebtsov, S. Laser beam welding of a CoCrFeNiMn-type high entropy alloy produced by self-propagating high-temperature synthesis. Intermetallics 2018, 96, 63-71. [CrossRef]

32. Shaysultanov, D.; Stepanov, N.; Malopheyev, S.; Vysotskiy, I.; Sanin, V.; Mironov, S.; Kaibyshev, R.; Salishchev, G.; Zherebtsov, S. Friction stir welding of a carbon-doped CoCrFeNiMn high-entropy alloy. Mater. Charact. 2018, 145, 353-361. [CrossRef]

33. Yurchenko, N.Y.; Panina, E.S.; Zherebtsov, S.V.; Tikhonovsky, M.A.; Salishchev, G.A.; Stepanov, N.D. Microstructure evolution of a novel low-density Ti-Cr-Nb-V refractory high entropy alloy during cold rolling and subsequent annealing. Mater. Charact. 2019, 158, 109980. [CrossRef]

34. Auwal, S.T.; Ramesh, S.; Yusof, F.; Manladan, S.M. A review on laser beam welding of titanium alloys. Int. J. Adv. Manuf. Technol. 2018, 97, 1071-1098. [CrossRef]

35. Akman, E.; Demir, A.; Canel, T.; Sınmazçelik, T. Laser welding of Ti6Al4V titanium alloys. J. Mater. Process. Technol. 2009, 209, 3705-3713. [CrossRef]

36. Li, Z.; Gobbi, S.L.; Norris, I.; Zolotovsky, S.; Richter, K.H. Laser welding techniques for titanium alloy sheet. J. Mater. Process. Technol. 1997, 65, 203-208. [CrossRef]

37. Liu, J.; Dahmen, M.; Ventzke, V.; Kashaev, N.; Poprawe, R. The effect of heat treatment on crack control and grain refinement in laser beam welded $\beta$-solidifying TiAl-based alloy. Intermetallics 2013, 40, 65-70. [CrossRef] 
38. Kashaev, N.; Ventzke, V.; Fomichev, V.; Fomin, F.; Riekehr, S. Effect of Nd:YAG laser beam welding on weld morphology and mechanical properties of Ti-6Al-4V butt joints and T-joints. Opt. Lasers Eng. 2016, 86, 172-180. [CrossRef]

39. Burkhardt, I.; Ventzke, V.; Riekehr, S.; Kashaev, N.; Enz, J. Laser welding and microstructural characterization of dissimilar $\gamma$-TiAl-Ti6242 joints. Intermetallics 2019, 104, 74-83. [CrossRef]

40. Oliver, W.C.; Pharr, G.M. Measurement of hardness and elastic modulus by instrumented indentation: Advances in understanding and refinements to methodology. J. Mater. Res. 2004, 19, 3-20. [CrossRef]

41. Senkov, O.N.; Zhang, C.; Pilchak, A.L.; Payton, E.J.; Woodward, C.; Zhang, F. CALPHAD-aided development of quaternary multi-principal element refractory alloys based on NbTiZr. J. Alloys Compd. 2019, 783, 729-742. [CrossRef]

42. Cahn, R.W.; Haasen, P. Physical Metallurgy; North-Holland Physics Pub.: Amsterdam, The Netherlands, 1983; ISBN 0444867872.

43. Senkov, O.N.; Woodward, C.F. Microstructure and properties of a refractory NbCrMo0.5Ta0.5TiZr alloy. Mater. Sci. Eng. A 2011, 529, 311-320. [CrossRef]

44. Kashaev, N.; Ventzke, V.; Petrov, N.; Horstmann, M.; Zherebtsov, S.; Shaysultanov, D.; Sanin, V.; Stepanov, N. Fatigue behaviour of a laser beam welded CoCrFeNiMn-type high entropy alloy. Mater. Sci. Eng. A 2019, 766, 138358. [CrossRef]

45. Martin, A.C.; Fink, C. Initial weldability study on A10.5CrCoCu0.1FeNi high-entropy alloy. Weld. World 2019, 63, 739-750. [CrossRef]

(C) 2019 by the authors. Licensee MDPI, Basel, Switzerland. This article is an open access article distributed under the terms and conditions of the Creative Commons Attribution (CC BY) license (http://creativecommons.org/licenses/by/4.0/). 